\title{
White and Blue Fingers: A Red Flag in Sickle Cell Disease
}

\author{
B. Mitchell Goodman III MD and Ian A. Chen, MD \\ Department of Medicine, Eastern Virginia Medical School, Norfolk, VA, USA.
}

J Gen Intern Med 28(3):477

DOI: $10.1007 / \mathrm{s} 11606-012-2238-7$

(c) Society of General Internal Medicine 2012

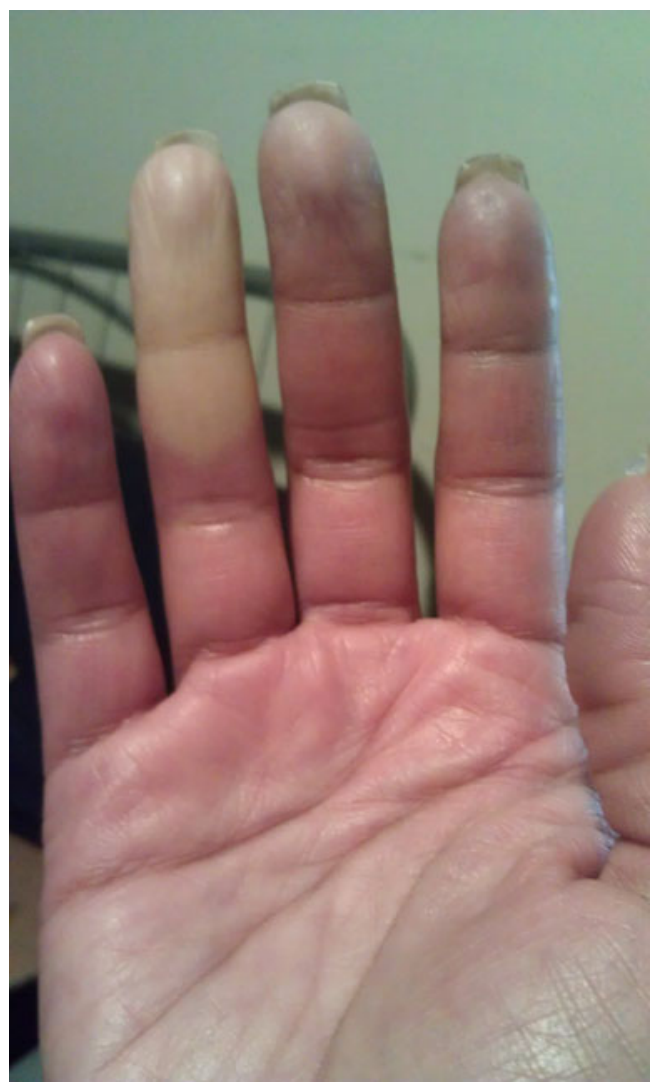

Figure 1. Raynaud's phenomenon exhibiting acral cyanosis, pallor, and erythema.

A

34-year-old woman with hemoglobin SC disease had intermittently painful and swollen wrists, metacarpophalangeal (MCP) and proximal interphalangeal (PIP) joints. She photographed her right hand after going outdoors for $10 \mathrm{~min}\left(41^{\circ} \mathrm{F}\right.$ air temperature). The photograph demonstrated pallor, cyanosis, and erythema (Fig. 1),

Received February 20, 2012

Revised June 18, 2012

Accepted September 12, 2012

Published online October 5, 2012 which abated after $10 \mathrm{~min}$ and were unrelated to pain crisis. Based on history and exam, she was diagnosed with Raynaud's phenomenon. Evaluation revealed an ANA of 1:320 and negative Smith, RF, and CCP antibodies. AntiRNP was elevated (25 EU/mL), suggesting possible mixed connective tissue disease and secondary Raynaud's phenomenon.

Hand pain and swelling in sickle cell disease can be from osteonecrosis, osteomyelitis, or hand-foot syndrome during vaso-occlusive crisis (up to $20 \%$ incidence before age two, but rare in adults). ${ }^{1,2}$ However, Raynaud's phenomenon is not known to be associated with sickle cell disease, and warrants further investigation for other possible etiologies to avoid misdiagnosis and treatment delays. ${ }^{3}$ Secondary Raynaud's may result from vasculopathy, endocrinopathy, drugs, malignancy, or connective tissue diseases. Evaluation may include ESR, ANA, RF, and other disease-specific antibodies (Scleroderma, SLE, MCTD, etc.), as indicated by history. Close monitoring of patients with negative studies may be warranted, as $1 \%$ per year may eventually develop a connective tissue disease. ${ }^{4}$

\section{Acknowledgements:}

Contributors: None

Funders: No internal or external funding sources

Prior presentations: None

Conflicts of Interest: The authors declare that they do not have a conflict of interest.

Corresponding Author: B. Mitchell Goodman, III, MD; Department of Medicine, Eastern Virginia Medical School, 825 Fairfax Avenue, Suite 410, Norfolk, VA 23507, USA (e-mail: goodmabm@evms.edu).

\section{REFERENCES}

1. Babhulkar SS, Pande K, Babhulkar S. The Hand-Foot Syndrome in Sickle-Cell Haemoglobinopathy. J Bone Joint Surg. 1995 (77-B):310-312.

2. Rao KP, Patel AR, Shah PC, Vohra R. Sickle cell dactylitis. Arch Intern Med. 1980;140(3):439-439.

3. Appenzeller S, Fattori A, Saad ST, Costallat LTL. Systemic lupus erythematosus in patients with sickle cell disease. Clin Rheumatol. 2008;27:359-364.

4. Spencer-Green G. Outcomes in primary raynaud phenomenon. A metaanalysis of the frequency, rates, and predictors of transition to secondary diseases. Arch Intern Med. 1998;158(6):595-600. 